and when choosing the top leaders of the legislative and executive bodies of the republican authorities the author suggests switching from ethnic criteria to the criteria of professionalism.

Keywords: Russian Federation, North Caucasus, federation, constituent entity, politics, power, national republic, ethnoterritorial principle, administrative-territorial principle

ОЗЕРОВ Александр Алексеевич - кандидат философских наук, доцент кафедры философии и религиоведения Военного университета Министерства обороны РФ; доцент департамента социологии, истории и философии Финансового университета при Правительстве РФ (125993, Россия, г. Москва, ГСП-3, Ленинградский пр-кm, 49; aоzerov@сатрus.muh.ru)

\title{
СМЫСЛОЖИЗНЕННЫЙ КОМПОНЕНТ РОССИЙСКОГО СОЦИУМА В УСЛОВИЯХ ПАНДЕМИИ COVID-19
}

Аннотация. Статья посвящена рассмотрению социологического аспекта смысложизненного компонента в контексте пандемии COVID-19. Рассматривая особенности состояния социума в период серьезных режимных преобразований в условиях распространения коронавирусной инфекции, автор выделяет индивидуальное и социальное измерения поисков проблемы смысла существования и существенное внимание уделяет исследованию внутриличностных особенностей понимания смысла существования в период кризиса.

Ключевые слова: философия, кризис, социология, психология, смысл жизни, личность

П роблема смысла жизни является актуальной во все исторические эпохи. Смысл существования искали как во времена всеобщего благоденствия, так и в периоды войн и революций, во времена эпидемий и пандемий. Особенно важное звучание данная проблема приобретает в кризисные этапы исторического развития, когда индивид невольно начинает искать причины негативных явлений в окружающем мире или в собственной личности.

Внезапно обрушившаяся на мир пандемия коронавируса, поражающая организм не только человека, но и некоторых животных [Шеметова и др. 2020: 209], оказала серьезное влияние на осмысление мира среднестатистическим человеком. Более того, данная проблема заставила также задуматься о будущем видных политиков и крупных бизнесменов, известных врачей и ученых с мировым именем.

Коронавирусная пандемия затронула практически все социальные слои России - сначала тех, кто был склонен путешествовать и оказался в странах, где было наибольшее число зараженных, а в дальнейшем эта проблема коснулась и рядовых жителей страны.

Не проходит и дня, когда бы не публиковались новости по теме пандемии и не приводилась бы статистика числа умерших от коронавируса и уже излечившихся. К счастью, в настоящее время можно наблюдать, что некоторые страны открываются, число исцелившихся увеличивается и ограничения постепенно снимаются. Но еще совсем недавно коронавирус порождал многочисленные теории заговоров и, казалось бы, давно забытые «пророчества» научной фантастики. Продолжает расти число фейковых новостей, вносящих рознь и неуверенность в российское общество. Вполне можно согласиться с А.В. Клеминым, 
утверждающим, что «фейковые новости опасны сами по себе. Общественное, государственное и личное благополучие может сильно пострадать и уже страдает от вбросов фальши в СМИ» [Клемин 2020: 169].

Таким образом, пандемический кризис внес и продолжает вносить дестабилизирующий вклад в российское общество, оставляя отпечаток на мировоззрении населения, изменяя общепринятые воззрения общества на мир и смысл существования.

Коронавирус как проблема современного социума - именно та сфера, которая находится на пересечении научных дисциплин, где факты и научные данные можно искать в социологии, психологии, а также в философии и истории. Для людей в такое непростое время востребованной становится информация религиозного, научного и научно-фантастического характера. «Использование искусственного интеллекта в медицине уже сегодня приносит миллиардные прибыли и экономит большие ресурсы в здравоохранении ведущих стран мира. В недалеком будущем искусственный интеллект полностью заменит человека в постановке диагнозов и назначении лечения при большинстве заболеваний», - утверждает В.М. Фершт [Фершт, Латкин, Иванова 2020: 129].

Согласиться можно также и с тем, что в условиях пандемии более важной становится и роль религиозных организаций. Так, Р.Н. Лункин утверждает, что «участие религиозных организаций в противодействии распространению вируса продемонстрировало, что они отнюдь не архаичны и отвечают на социальные вызовы. Для многих, прежде всего для православных, кризис остро поставил проблему выработки новых форм христианской миссии и привлечения населения в церковь. Во многих странах пандемия помогла развитию межрелигиозного диалога. Социальные изменения, вызванные пандемией коронавируса, обострили имеющиеся проблемы и ускорили те процессы, которые уже проходили во внутрицерковной жизни» [Лункин 2020: 108].

Некоторые исследователи убеждены, что в условиях распространения коронавируса произойдут изменения в политической жизни государства. Так, среди ученых Иркутского государственного университета бытует мнение, что либерализм в России перестанет быть популярным и в условиях новой реальности будет вытеснен окончательно: «Продолжится вымывание либерально ориентированной части государственного аппарата. Эти процессы пошли с начала 2010-х гг. и развиваются по восходящей, представляется, что кризис и трагедии, вызванные эпидемией, ускорят их» [Зуляр 2020: 6].

Для некоторых же, напротив, отступление от либеральных ценностей становится тревожным сигналом. В.И. Терентьева отмечает, что «политологи видят проблему неэффективности наднациональных институтов в борьбе с эпидемией и видят ее решение в укреплении антилиберальной тенденции, для которой характерны изоляционизм, протекционизм, национальный центризм. Выживание общества в условиях эпидемиологической опасности стало важным оправданием для централизации управления, ограничительных мер и мобилизационных экономических методов» [Терентьева 2020: 9].

В обычных условиях существования индивид, как правило, воспринимает окружающий мир не таким, какой он есть, во всех его оттенках, в его объективности, а с учетом собственного мировоззренческого опыта, предпосылок, внутренних стереотипов, сквозь призму автоматического мировосприятия. При этом можно отметить, что здесь отсутствует понимание мира как «вещи в себе», оно опосредовано жизненным опытом человека. Повседневная жизнь в своей рутине и стереотипности мешает индивиду увидеть окружающую действительность такой, какая она есть, и лишь в переломные эпохи развития общества, когда заведенный порядок нарушается внешними факторами, раз- 
личными событиями чрезвычайного характера, человек способен обратить на происходящее все свое внимание и заметить детали.

Tо, что в английском языке называется mindfulness - состояние полного внимания, внимательности, свойственно не только особому состоянию медитации, когда личность не погружается в мир мантр и фантазий, а в состоянии ясного ума рассматривает действительность. Это также может быть применимо к человеку, который, например, в силу той или иной экстремальной ситуации, пришедшей извне, после того, как стихло стрессовое состояние, все свое внимание стал обращать на происходящее, при этом замечая различные нюансы и оттенки окружающего мира.

С учетом сказанного выше можно отметить, что пандемия способна не только дестабилизировать социум; она также способна кристаллизировать его, сплачивать изнутри ради борьбы за более безопасное будущее. Это связано с тем, что в переломные исторические эпохи события, которым не было места в саморегулирующемся обществе, начинают приковывать к себе внимание не только простых обывателей, но и, что наиболее важно, специалистов и профессионалов своего дела.

Здесь можно сделать два вывода. Во-первых, коренные социальные преобразования, способствующие повышению внимательности и сознательности населения, могут также способствовать оздоровлению психологического состояния народа, поскольку повышенная внимательность и нахождение в настоящем (в отличие от диссоциативных, отвлеченных и «выключенных» состояний) - признак здоровой психики. Во-вторых, преобразования не могут длиться долго, потому что кризисные явления требуют немедленного вмешательства специалистов и их эффективной работы. Но даже такая краткосрочность может быть использована на благо народа и государства для реализации долгосрочных целей, например для улучшения состояния морали и нравственности в обществе.

Внутренние процессы, связанные с усилением смысложизненного компонента в жизни индивида в кризисных условиях, обусловлены его инстинктами и потребностями, наиболее существенными из которых может быть стремление к наслаждению и боязнь жизненных потерь.

Пандемия коронавируса, которая сама по себе выступает в качестве кризисного явления, своего рода переломного момента, способствует изменению поведения людей. Сейчас уже нет привычной нормальности (вместо этого есть состояние социума, которое в англоязычных СМИ называют new normal). Во многих местах планеты введены строгие меры по самоизоляции, и все это определенным образом влияет на мировоззрение человека.

Однако, если иметь в виду психологический аспект интересующего нас вопроса, можно сделать некоторые исключения с учетом современной психологии. Дело в том, что далеко не все люди боятся чего-либо в равной степени. Существуют и такие, для которых даже серьезные потрясения не будут поводом для страха или размышлений о смысле существования. Имеются в виду индивиды, которых в современной западной психологии принято называть людьми с дефектами личности и сниженной или и вовсе отсутствующей способностью различать добро и зло, делать для себя выводы морально-нравственного плана (совестливость). Это персоналии, у которых в период становления личности была нарушена система социализации. Такие индивиды способны нарушить любые законы и нормы (если это открыто-агрессивный тип личности) или же нарушать их скрытно (в случае, если речь идет о скрытно-агрессивном типе личности).

В связи с этим в свете мер, направленных на стабилизацию ситуации, связан- 
ной с распространением коронавирусной инфекции, необходимо иметь в виду, что люди реагируют на кризис по-разному. Особо впечатлительные и совестливые, как правило, сразу готовы исполнять предписания и выполнять все требования властей. Те же, у кого совести меньше или она вообще отсутствует, могут и вовсе не обращать внимания на требования под разными предлогами. Главным образом, как уже отмечалось выше, это относится к людям с психическими отклонениями личности.

В структуре смысложизненной матрицы необходимо создать системный статистический комплекс по учету общественного мнения населения России по различным вопросам. Необходимо также иметь в виду рейтинг различных лиц государства на фоне тех или иных событий, для того чтобы принимать взвешенные решения в условиях будущих кризисных явлений. В данной системе необходимо учитывать мировоззренческие и психологические особенности русского народа, его отношение к проблеме смысла жизни.

Важно отметить, что ситуация и меры, связанные с пандемией коронавируса, беспрецедентны, и подобной ситуации еще не было в обозримом прошлом. В связи с этим важно принимать правильные и эффективные меры, направленные на стабилизацию эпидемиологической, экономической и социальной обстановки в российском обществе. Помимо чисто объективной стороны существующей проблемы, важно не забывать и морально-психологическую составляющую. Необходимо учитывать нравственное состояние народа, то, как он справляется со сложной ситуацией. Здесь также необходимо отметить, что улучшение материальной стороны жизни населения России способствовало бы улучшению и духовности народа, создавало бы предпосылки для патриотического воспитания как взрослых, так и подрастающего поколения.

Стоит также учитывать, что в процессе морально-нравственного оздоровления российского общества необходимо опираться на результаты не только отечественных научных разработок, но и на общемировые тренды научной мысли.

Кроме того, в процессе исследования смысла жизни и развития смысложизненной матрицы было бы полезным проводить психологическое исследование населения страны и использовать полученные данные для целостного анализа и совокупного рассмотрения всех нюансов психологического портрета среднестатистического россиянина.

Особое внимание должно уделяться работе по патриотическому воспитанию. Даже в условиях пандемии данная деятельность должна проводиться на высоком уровне. Переломные эпохи истории не должны стать преградой в развитии патриотизма и любви к Отечеству.

Для реализации методик и программ, направленных на положительное осмысление окружающей действительности, прежде всего необходимо провести анализ смысложизненных предпочтений и мировоззренческих особенностей населения в рамках социологического исследования, которое смогло бы охватить все социальные слои граждан России.

В связи с этим необходимо учитывать все особенности, касающиеся российского общества, - не только экономические, социальные, но и непосредственно психологические. Специфика, обусловленная психологическими особенностями населения, позволит выделить наиболее уязвимые сферы социума, которым требуется больше внимания исследователей.

Если в ходе формирования социальной сферы в доперестроечное время, в условиях Советского государства руководство страны старалось создать равные условия для развития и трудовой деятельности населения, то теперь, 
в современных условиях наметилось создание уникальных социальных групп на тех или иных территориях. Например, есть различные коттеджные поселки, жители которых преимущественно имеют высшее образование, высокий уровень и качество жизни, доступ к высококлассной медицинской помощи. Такие люди могут отличаться хорошим физическим и психическим здоровьем. Пандемия коронавируса их не затронет радикальным образом, поскольку забота о здоровье у данных лиц нередко культивируется еще с детства.

Некоторые другие социальные группы могут характеризоваться низким уровнем качества жизни, недостаточным доступом к ресурсам здравоохранения и зачастую нежеланием заботиться о собственном здоровье. Среди таких людей может быть большое число хронических заболеваний как физического, так и психического спектра. Социальные группы данного спектра пандемия может затронуть непосредственно и нанести серьезный ущерб.

Таким образом, в процессе рассмотрения возможностей создания программ и методик по улучшению морально-нравственного состояния российского общества, совершенствованию его смысложизненного компонента, связанного с состоянием физического и психического здоровья, необходимо учитывать отмеченные выше особенности. Российское общество сейчас далеко не однородно, и дифференцированный подход сегодня важен как никогда раньше, особенно в условиях пандемии.

\section{Список литературы}

Зуляр Ю.А. 2020. Коронавирус как миропреобразующий феномен? Известия Иркутского государственного университета. Т. 32. С. 4-6.

Клемин А.В. 2020. Права человека и возможности их ограничения. Актуальные проблемы экономики и права. Т. 14. № 1. С. 165-173.

Лункин Р.Н. 2020. Механизмы религиозной реакции на пандемию коронавируса. - Научно-аналитический вестник Института Европы РАН. № 2. С.104109.

Терентьева В.И. 2020. Война, эпидемия, духовно-ментальное обнищание - что станет «Ноевым ковчегом» сегодня? К 75-летию Великой Победы! Вестник Восточно-Сибирской открытой академии № 37.

Фершт В.М., Латкин А.П., Иванова В.Н. 2020. Современные подходы к использованию искусственного интеллекта в медицине. - Территория новых возможностей. Вестник Владивостокского государственного университета экономики и сервиса. Т. 12. № 1(48). С. 121-130.

Шеметова Е.Г., Шахова Д.Д., Иванова А.К., Морозов Н.В. 2020. Актуальные аспекты обеспечения безопасности человека при коронавирусе. - Молодежь и наука: шаг к успеху: сборник научных статей 4-й Всероссийской научной конференции перспективных разработок молодых ученых (отв. ред. А.А. Горохов). Курск: Изд-во Юго-Западного государственного университета. С. 209-212. 
OZEROV Aleksandr Alekseevich, Cand.Sci. (Philos.), Associate Professor of the Chair of Philosophy and Religious Studies, Military University of the Ministry of Defense of Russia; Associate Professor of the Department of Sociology, History and Philosophy, Financial University under the Government of the Russian Federation (49 Leningradsky Ave, GSP-3, Moscow, Russia, 125993; aozerov@campus.muh.ru)

\section{THE LIFE-MEANING COMPONENT OF RUSSIAN SOCIETY IN THE CONTEXT OF THE COVID-19 PANDEMIC}

Abstract. The article is devoted to consideration of the sociological aspect of the meaning-life component in the context of the COVID-19 pandemic. Considering the features of the state of society during the period of serious regime transformations in the context of the spread of coronavirus infection, the author highlights individual and social dimensions of the search for the problem of the meaning of existence. The author pays substantial attention to the study of intrapersonal features of understanding the meaning of existence during the crisis.

Keywords: philosophy, crisis, sociology, psychology, meaning of life, personality

ДОРОЖКИН Юрий Николаевич - доктор философских наук, профессор; заведующий кафедрой политологии, социологии и философии Башкирской академии государственной службы и управления при Главе Республики Башкортостан (450008, Россия, Республика Башкортостан, г. Уфа, ул. Заки Валиди, 40; dorword@таil.ru)

\section{РОССИЙСКОЕ ГОСУДАРСТВО: МНОГО ЕГО СЕГОДНЯ ИЛИ МАЛО?}

Аннотация. В статье анализируется роль и участие государства в разных сферах общественно-политической и социально-экономической жизни России. Автор приходит к выводу об избыточности государства во всех рассматриваемых сферах, вследствие чего происходит деформация российской политической системы, затрудняющая последовательное и системное развитие страны.

Ключевые слова: политическая система, государственное участие, федерализм, Россия

B последнее время, особенно в связи с коронавирусной пандемией, актуализировалась и обрела новое дыхание дискуссия о месте и роли государства в современном обществе. Стали вновь писать о настоятельной потребности в сильном государстве. Так, председатель комиссии Совета Федерации кандидат исторических наук А. Пушков утверждает: «В посткоронавирусном мире неизбежно усилится - и будет востребована - роль государства. Именно государство, тысячи раз ошельмованное и заклейменное либералами как источник чуть ли не всех бед индивида, вернется на авансцену как единственный фактор, способный сражаться с новыми угрозами - как отдельному индивиду, так и человечеству в целом. В условиях эпидемии государство, напротив, из “аппарата насилия” превращается в “аппарат спасения” граждан от угрозы, с которой по определению не способен справиться частный сектор и перед которой в ужасе замирает т.н. “давосский человек” с его культом индивидуализма, денег и либеральных ценностей. "Нам сказали, что государство нужно упразднить. Что частное лучше общественного. Что государство - зло. Что больницы 